\title{
Mapping of Land Suitability for Rambutan (Nephelium lappaceum) in Community Agroforestry Land at Gunung Ambat Village and Simpang Kuta Buluh Village
}

\author{
Rahmawaty ${ }^{1)}$, Sintike Frastika ${ }^{1)}$, Ridwanti Batubara ${ }^{1)}$ and Abdul Rauf ${ }^{2)}$ \\ ${ }^{1)}$ Faculty of Forestry, Universitas Sumatera Utara, Jl. Tridharma Ujung No.1, Kampus USU Medan, Sumatera \\ Utara, Indonesia 20155 \\ ${ }^{2)}$ Faculty of Agriculture, Universitas Sumatera Utara, Medan, Sumatera Utara, Indonesia 20155 \\ e-mail:rahmawaty@usu.ac.id
}

Received October 1, 2019; Revised Februari 19, 2020; Accepted 15 April 2020

\begin{abstract}
Rambutan (Nephelium lappaceum) is Sapindaceae family, commonly found in agroforestry land, owned by the community in Langkat District, North Sumatra Province as One of Multy Purpose Tree Species. This study aimed to asses and map the distribution land suitability for $N$. lappaceum. This research was conducted in Gunung Ambat Village and Simpang Kuta Buluh Village, Sei Bingai Sub District, Langkat Regency using survey method. The soil samples data was collected in the field based on the land unit. Land suitability assessment was evaluated using matching method. To map the distribution of land suitability, the Geographic Information System (GIS) was used. Global Positioning System (GPS) also was used in this study to record the coordinate points of each soil sample from the field. The results indicate that the actual land suitability classes for $N$. lappaceum were dominated by moderately suitable (S2) (97.56\%) in Gunung Ambat Village and moderately suitable (S2) (52.92\%) in Simpang Kuta Buluh Village. The water availability (wa) and root zone medium (rc) were the dominant limiting factor in this area.
\end{abstract}

Keywords: Agroforestry, GIS, GPS, MPTS, Rambutan

\begin{abstract}
ABSTRAK
Rambutan (Nephelium lappaceum) adalah keluarga Sapindaceae, umumnya ditemukan di lahan agroforestri yang dimiliki oleh masyarakat di Kabupaten Langkat, Provinsi Sumatera Utara sebagai salah satu pohon serbaguna. Penelitian ini bertujuan untuk menilai dan memetakan sebaran kesesuaian lahan rambutan. Penelitian ini dilakukan di Desa Gunung Ambat dan Desa Simpang Kuta Buluh, Kecamatan Sei Bingai, Kabupaten Langkat dengan menggunakan metode survei. Data sampel tanah dikumpulkan di lapangan berdasarkan unit tanah. Penilaian kesesuaian lahan dievaluasi dengan menggunakan metode pencocokan. Untuk memetakan distribusi kesesuaian lahan digunakan Sistem Informasi Geografis (SIG). Global Positioning System (GPS) juga digunakan dalam penelitian ini untuk mengetahui titik koordinat dari setiap sampel tanah di lapangan. Hasil penelitian menunjukkan bahwa kelas kesesuaian lahan aktual untuk $N$. lappaceum didominasi oleh kelas cukup sesuai (S2) $(97,56 \%)$ di Desa Gunung Ambat dan cukup sesuai (S2) (52,92\%) di Desa Simpang Kuta Buluh. Ketersediaan air dan media perakaran (rc) merupakan faktor pembatas dominan di lokasi penelitian.
\end{abstract}

Kata Kunci: Agroforestri, GIS, GPS, MPTS, Rambutan

\section{INTRODUCTION}

Land suitability is used as a basis for rational land use planning. It needs consideration in land use

J Trop Soils, Vol. 25, No. 2, 2020: 107-117

ISSN 0852-257X; E-ISSN 2086-6682 decision making so that land can be used optimally and sustainably. Several studies about land suitability have conducted for some plants in several locations based on GIS (e.g. Rahmawaty et al. 2019a; Rahmawaty et al. 2019c; Rahmawaty et al. 2019d; Harahap et al. 2019; Parry et al. 2018; Tarigan et al. 2016; Rahmawaty et al. 2016; Satriawan et al. 
2014; Rahmawaty et al. 2012; Chuong 2007). Several approaches have been used to analyze the suitability of land (e.g. Malczewski 2004; Chandio et al. 2011; He et al. 2011; Elsheikh et al., 2013; El Baroudy 2016; Mazahreh et al. 2019). There is a tool that can be applied for forestry and agriculture such as land suitability, namely: Geographical Information System (GIS). It has been widely applied in various fields. Land evaluation results can be described in the form of maps using GIS technology. According to Rahmawaty et al. (2019a) and Rahmawaty et al. (2012), one application of GIS is mapping the results of land evaluation and presenting the results in the form of maps to show the spatial distribution of geographical phenomena. The GIS is used for data collection, storage, analysis, and manipulation of geographic references (Pan and Pan 2012; Rahmawaty et al. 2013; Elsheikh et al., 2013; Rahmawaty et al. 2015; Rahmawaty et al. 2017a, Rahmawaty et al. 2017b, Rahmawaty et al. 2019a, Rahmawaty et al. 2019b). It has been widely applied in various fields, including land evaluation (Rahmawaty et al. 2019a; Mazahreh et al. 2019; Parry et al. 2018; Satriawan et al. 2015; Rahmawaty et al. 2012).

Indonesia has a mega-diversity of natural resources. One of the most important biodiversity is $N$. lappaceum. One place that has the potential to be found $N$. lappaceum, namely Langkat District, North Sumatra, Indonesia. In this area, N. lappaceum is known as the local name "rambutan binjai". It can be found in several places, including on community lands, such as in the agroforestry pattern. It is believed to be native to the Malay Archipelago. It is native to Indonesia and Southeast Asia. It is closely related to several other edible tropical fruits in Indonesian, Filipino and Malay, it literally means hairy caused by the 'hair' that covers this fruit. According to Mahmood et al. (2018), rambutan fruit has been proven to possess phytochemicals that demonstrate anticancer, anti-obesity, anti-allergic, antidiabetic, antiHIV, antimicrobial, anti-hypercholesterolemia, antidengue and anti-hyperglycemic effects in varied invitro and in-vivo models. Development of $N$. lappaceum to improve the economy of rural communities specially in Sei Bingai District, Langkat District, North Sumatra Province. Many studies also have been reported about $N$. lappaceum in different places, (e.g. Rahayu et al., 2013; Chiaw et al. 2014; Muhtadi et al. 2015; Sukmandani et al. 2017; Mirghani 2019). Furthermore, Mohamed et al. (2019), have been studied about natural diversity of rambutan (N. lappaceum L.) in Kerala, India; Syarifuddin et al. (2018) have been reported about the impact of oil palm plantation on the ecology of rambutan insect pollinators in North Sumatra, Indonesia;

Ahmad et al. (2017) have been researched geraniin extracted from the rind of $N$. lappaceum binds to dengue virus type- 2 in Malaysia. Research on a mapping of land suitability for $N$. lappaceum as one of agroforestry plants has never been conducted, especially in this location. There is a lack of data and information on N. lappaceum land suitability in Langkat District, hence, this study aimed to evaluate the actual land suitability class and map the land suitability classes for $N$. lappaceum in Gunung Ambat Village and Simpang Kuta Buluh Village, Sei Bingai Sub District, Langkat, North Sumatra, Indonesia.

\section{MATERIALS AND METHODS}

\section{Study Area}

This research was conducted in Gunung Ambat Village and Simpang Kuta Buluh Village, Sei Bingai Sub District, Langkat, North Sumatra, Indonesia (Figure 1). The total area of Gunung Ambat Village is 1990.13 ha and the total area of Simpang Kuta Buluh Village is 765.20 ha.

\section{Data Collection}

This research was conducted from February to July 2019. The survey method was conducted to collect soil samples in the field based on the land unit (Zonneveld 1989). Land units obtained from overlay results from land-use map, soil map and slope map of Gunung Ambat Village and Simpang Kuta Buluh Village, Sei Bingai Sub District, Langkat, North Sumatra, Indonesia. There were seven land units in this area. The land units have their characteristics. The land characteristics were temperature (tc), water availability (annual rainfall) (wa), oxygen availability (drainage) (oa), root zone medium (texture, soil depth) (rc), nutrients retention (cation exchange capacity, base saturation, $\mathrm{pH}, \mathrm{C}$ organic), sodicity (alkalinity) (nr), slope and soil erosion (eh), and flood hazard (fh). According to the reference and criteria were adopted from the land suitability for Agricultural Plants by the Centre for Soil and Agroclimate Research, Bogor-Indonesia (Djaenudin et al. 2003), Hardjowigeno and Widiatmaka (2007), highly suitable (S1) Criteria for N. lappaceum, namely: temperature (tc) is $22-28$ ${ }^{\circ} \mathrm{C}$, annual rainfall (wa) is $1000-2000 \mathrm{~mm}$, oxygen availability (oa) is Well-drained, fine texture, slope less than $8 \%$ and erosion hazard is very low. Not suitable $(\mathrm{N})$ Criteria for $N$. lappaceum, namely: 


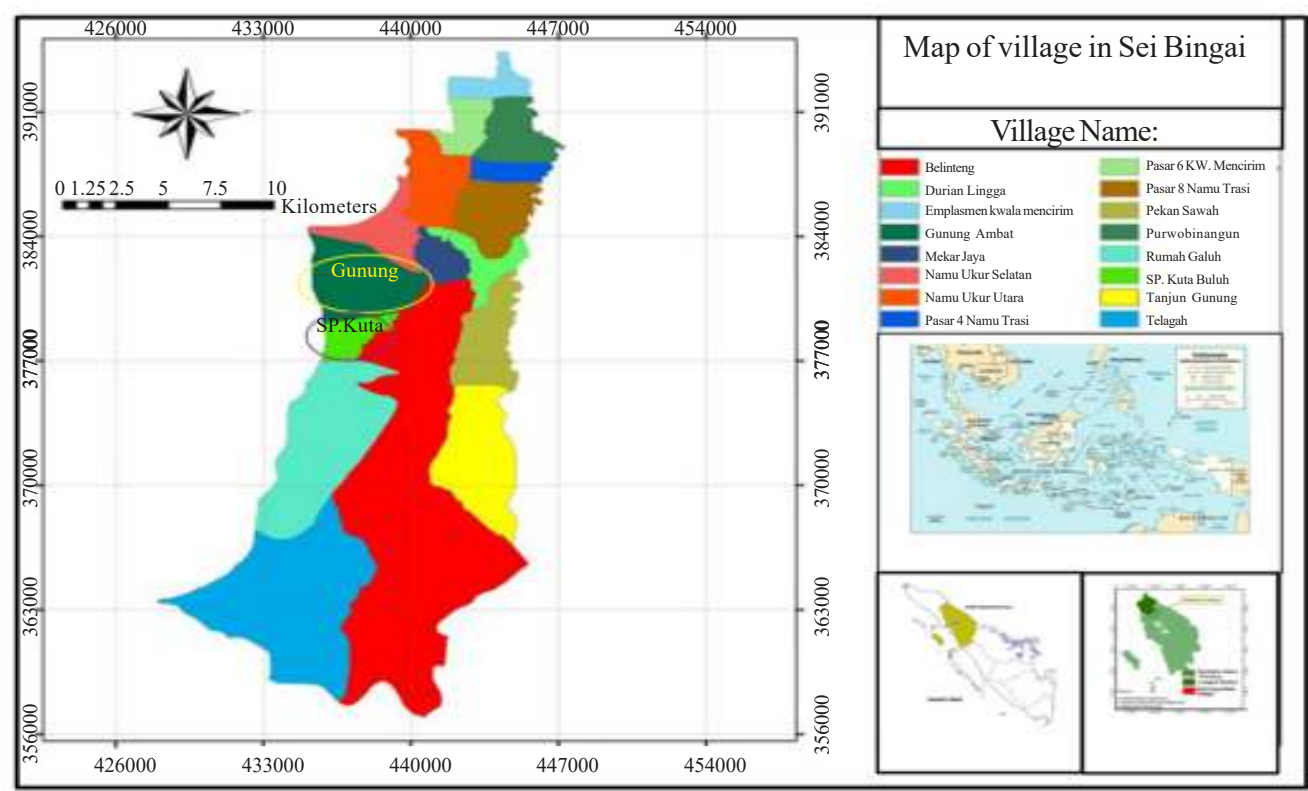

Figure 1. Map of Gunung Ambat Village and Simpang Kuta Buluh Village, Sei Bingai Sub District, Langkat, North Sumatra, Indonesia

temperature (tc) is more than $40^{\circ} \mathrm{C}$, annual rainfall (wa) is more than $4000 \mathrm{~mm}$, drainage is poor, rough texture, slope more than $30 \%$ and erosion hazard is very high (Table 1).

\section{Data analysis}

The matching method was used to evaluate land suitability classification (Ritung et al. 2007; Ritung

Table 1. Land characteristics and land suitability criteria for rambutan (N. lappaceum).

\begin{tabular}{|c|c|c|c|c|}
\hline \multirow[t]{2}{*}{ Land Characteristics } & \multicolumn{4}{|c|}{ land suitability criteria for rambutan (N. lappaceum) } \\
\hline & $\mathrm{S} 1$ & $\mathrm{~S} 2$ & $\mathrm{~S} 3$ & $\mathrm{~N}$ \\
\hline $\begin{array}{l}\text { Temperature (tc) } \\
\left({ }^{\circ} \mathrm{C}\right)\end{array}$ & $22-28$ & $28-34$ & $34-40$ & $>40$ \\
\hline Water availability (wa) & & & & \\
\hline $\begin{array}{l}\left.\text { Rainfall (mm year }{ }^{-1}\right) \\
\text { Oxygen availability (oa) }\end{array}$ & $1000-2000$ & $2000-3000$ & $3000-4000$ & $>4000$ \\
\hline Drainage & $\begin{array}{l}\text { Well drained, } \\
\text { medium, }\end{array}$ & $\begin{array}{l}\text { Moderately poorly } \\
\text { drained }\end{array}$ & $\begin{array}{c}\text { poorly } \\
\text { drained, } \\
\text { moderately } \\
\text { excessively } \\
\text { drained }\end{array}$ & $\begin{array}{l}\text { Very poorly } \\
\text { drained, } \\
\text { excessively } \\
\text { drained, }\end{array}$ \\
\hline Root zone medium (rc) & & & & \\
\hline Texture & $\begin{array}{l}\text { Medium- } \\
\text { Moderately } \\
\text { fine, Fine }\end{array}$ & - & $\begin{array}{l}\text { Moderately } \\
\text { coarse }\end{array}$ & Coarse \\
\hline Soil depth (cm) & $>100$ & $75-100$ & $50-75$ & $<50$ \\
\hline Nutrient retention (nr) & & & & \\
\hline $\mathrm{CEC}\left(\mathrm{me} 100 \mathrm{~g}^{-1}\right)$ & $>16$ & $\leq 16$ & - & - \\
\hline $\mathrm{pH} \mathrm{H} \mathrm{H}_{2} \mathrm{O}$ & $5.0-6.0$ & $4.5-5.0$ & $<4.5$ & - \\
\hline & & $6.0-7.5$ & $>7.5$ & - \\
\hline Organic-C (\%) & $>1.2$ & $0.8-1.2$ & $<0.8$ & - \\
\hline Erosion hazard (eh) & & & & \\
\hline Slope $(\%)$ & $<8$ & 8-16 & $16-30$ & $>30$ \\
\hline $\begin{array}{l}\text { Erosion hazard } \\
\text { Flood hazard (fh) }\end{array}$ & Very low & Low-medium & High & Very high \\
\hline Inundation & F0 & $\mathrm{F} 1$ & $\mathrm{~F} 2$ & $>\mathrm{F} 2$ \\
\hline
\end{tabular}

Source: The Centre for Soil and Agroclimate Research, Bogor (2003); Djaenudin et al. (2003), Hardjowigeno and Widiatmaka (2007). Note : $\mathrm{S} 1=$ highly suitable, $\mathrm{S} 2=$ moderately suitable, $\mathrm{S} 3=$ marginally suitable, $\mathrm{N}=$ not suitable $\mathrm{F} 0=$ none, F1 = low, F2 = medium, F3 = moderately high, F4 = very high. 
et al. 2011). It is matching the data that has been obtained both from the field and from laboratory with land use requirements for $N$. lappaceum. The assessment and presentation of land suitability class results were based on FAO (1976) and FAO (1983), namely: Highly suitable (S1), Moderately suitable (S2), marginal suitable (S3), and not suitable (N) (Soil Research Center 2003, Arsyad 2010; Rahmawaty et al. 2011). The GIS was used to map the land suitability classes. The land units were used as a place to take soil samples in the field. The results of the assessment of the land suitability classes were presented in the form of tables and maps that provide a class description of the land suitability of $N$. lappaceum (Table 2 to Table 8).

To record the coordinate points of soil samples, the global positioning system (GPS) was used (Rahmawaty et al. 2016; Rahmawaty et al. 2018). The GIS was used to show the spatial distribution of land suitability classes.

Table 2. Actual land suitability classification for Rambutan (N. lappaceum) in Land Unit I based on the matching method.

\begin{tabular}{|c|c|c|}
\hline Land characteristics & Field/laboratory data & Actual land suitability \\
\hline \multicolumn{3}{|l|}{ Temperature (tc) } \\
\hline$\left({ }^{\circ} \mathrm{C}\right)$ & $23{ }^{\circ} \mathrm{C}-24{ }^{\circ} \mathrm{C}$ & S1 \\
\hline \multicolumn{3}{|l|}{ Water availability (wa) } \\
\hline Rainfall (mm year-1) & 2010 & $\mathrm{~S} 2$ \\
\hline \multicolumn{3}{|l|}{ Oxygen availability (oa) } \\
\hline Drainage & Well drained & S1 \\
\hline \multicolumn{3}{|l|}{ Root zone medium (rc) } \\
\hline Texture & Fine & S1 \\
\hline Soil depth $(\mathrm{cm})$ & 60 & S3 \\
\hline \multicolumn{3}{|l|}{ Nutrient retention (nr) } \\
\hline $\operatorname{CEC}\left(\operatorname{me} 100 \mathrm{~g}^{-1}\right)$ & 22.25 & $\mathrm{~S} 1$ \\
\hline $\mathrm{pH} \mathrm{H}_{2} \mathrm{O}$ & 6.66 & S2 \\
\hline Organic-C (\%) & 1.47 & $\mathrm{~S} 1$ \\
\hline \multicolumn{3}{|l|}{ Erosion hazard (eh) } \\
\hline Slope $(\%)$ & $15 \%$ & S2 \\
\hline Erosion hazard & Very low & $\mathrm{S} 1$ \\
\hline \multicolumn{3}{|l|}{ Flood hazard (fh) } \\
\hline Inundation & F0 & S1 \\
\hline Actual land suitability evaluation & & $\mathrm{S} 3, \mathrm{rc}$ \\
\hline
\end{tabular}

Table 3. Actual land suitability classification for Rambutan (N. lappaceum) in Land Unit II based on the matching method.

\begin{tabular}{|c|c|c|}
\hline Land characteristics & Field/laboratory data & Actual land suitability \\
\hline \multicolumn{3}{|l|}{ Temperature (tc) } \\
\hline$\left({ }^{\circ} \mathrm{C}\right)$ & $23{ }^{\circ} \mathrm{C}-24{ }^{\circ} \mathrm{C}$ & S1 \\
\hline \multicolumn{3}{|l|}{ Water availability (wa) } \\
\hline Rainfall (mm year $\left.{ }^{-1}\right)$ & 2010 & $\mathrm{~S} 2$ \\
\hline \multicolumn{3}{|l|}{ Oxygen availability (oa) } \\
\hline Drainage & Well drained & S1 \\
\hline \multicolumn{3}{|l|}{ Root zone medium (rc) } \\
\hline Texture & Fine & S1 \\
\hline Soil depth $(\mathrm{cm})$ & 70 & S3 \\
\hline \multicolumn{3}{|l|}{ Nutrient retention (nr) } \\
\hline $\mathrm{CEC}\left(\mathrm{me}^{\left.100 \mathrm{~g}^{-1}\right)}\right.$ & 19.49 & S1 \\
\hline $\mathrm{pH} \mathrm{H} \mathrm{H}_{2} \mathrm{O}$ & 6.45 & $\mathrm{~S} 2$ \\
\hline Organic-C (\%) & 1.48 & S1 \\
\hline \multicolumn{3}{|l|}{ Erosion hazard (eh) } \\
\hline Slope (\%) & $30 \%$ & S3 \\
\hline Erosion hazard & Very low & S1 \\
\hline \multicolumn{3}{|l|}{ Flood hazard (fh) } \\
\hline Inundation & F0 & $\mathrm{S} 1$ \\
\hline Actual land suitability evaluation & & $\mathrm{S} 3, \mathrm{rc}, \mathrm{eh}$ \\
\hline
\end{tabular}


Table 4. Actual land suitability classification for Rambutan (N. lappaceum) in Land Unit III based on the matching method.

\begin{tabular}{lll}
\hline Land characteristics & Field/laboratory data & Actual land suitability \\
\hline $\begin{array}{l}\text { Temperature (tc) } \\
\left({ }^{\circ} \mathrm{C}\right)\end{array}$ & $23{ }^{\circ} \mathrm{C}-24^{\circ} \mathrm{C}$ & $\mathrm{S} 1$ \\
$\begin{array}{l}\text { Water availability (wa) } \\
\left.\text { Rainfall (mm year }{ }^{-1}\right)\end{array}$ & & \\
$\begin{array}{l}\text { Oxygen availability (oa) } \\
\text { Drainage }\end{array}$ & 2010 & $\mathrm{~S} 2$ \\
$\begin{array}{l}\text { Root zone medium (rc) } \\
\text { Texture }\end{array}$ & Well drained & $\mathrm{S} 1$ \\
Soil depth (cm) & Fine & $\mathrm{S} 1$ \\
Nutrient retention (nr) & 98 & $\mathrm{~S} 2$ \\
CEC (me 100 $\left.\mathrm{g}^{-1}\right)$ & & \\
pH $\mathrm{H}_{2} \mathrm{O}$ & 22.25 & $\mathrm{~S} 1$ \\
Organic-C (\%) & 6.51 & $\mathrm{~S} 2$ \\
Erosion hazard (eh) & 2.42 & $\mathrm{~S} 1$ \\
Slope (\%) & $15 \%$ & $\mathrm{~S} 2$ \\
Erosion hazard & Very low & $\mathrm{S} 1$ \\
Flood hazard (fh) & & $\mathrm{S} 1$ \\
Inundation & $\mathrm{F} 0$ & $\mathrm{~S} 2 \mathrm{wa}, \mathrm{rc}, \mathrm{nr}, \mathrm{eh}$ \\
\hline Actual land suitability evaluation & & \\
\hline
\end{tabular}

Table 5. Actual land suitability classification for Rambutan (N. lappaceum) in Land Unit IV based on the matching method.

\begin{tabular}{llc}
\hline Land characteristics & Field/laboratory data & Actual land suitability \\
\hline $\begin{array}{l}\text { Temperature (tc) } \\
\left({ }^{\circ} \mathrm{C}\right)\end{array}$ & $23{ }^{\circ} \mathrm{C}-24^{\circ} \mathrm{C}$ & $\mathrm{S} 1$ \\
$\begin{array}{l}\text { Water availability (wa) } \\
\left.\text { Rainfall (mm year }{ }^{-1}\right)\end{array}$ & $\mathrm{S} 2$ \\
$\begin{array}{l}\text { Oxygen availability (oa) } \\
\text { Drainage }\end{array}$ & 2010 & $\mathrm{~S} 1$ \\
$\begin{array}{l}\text { Root zone medium (rc) } \\
\text { Texture }\end{array}$ & Well drained & $\mathrm{S} 1$ \\
Soil depth (cm) & Moderately fine & $\mathrm{S} 2$ \\
Nutrient retention (nr) & 97 & $\mathrm{~S} 1$ \\
CEC (me $\left.100 \mathrm{~g}^{-1}\right)$ & & $\mathrm{S} 2$ \\
pH $\mathrm{H}_{2} \mathrm{O}$ & 21.22 & $\mathrm{~S} 1$ \\
Organic-C (\%) & 6.43 & $\mathrm{~S} 2$ \\
Erosion hazard (eh) & 1.51 & $\mathrm{~S} 1$ \\
Slope (\%) & & \\
Erosion hazard & $15 \%$ & $\mathrm{~S} 1$ \\
Flood hazard (fh) & Very low & $\mathrm{S} 2$ wa,rc,nr,eh \\
Inundation & & \\
Actual land suitability evaluation & F0 & \\
\hline
\end{tabular}

\section{RESULTS AND DISCUSSION}

The actual land suitability classes area for $N$. lappaceum in Gunung Ambat Village is presented in Figure 2.

The actual land suitability classes for $N$. lappaceum were moderately suitable (S2) $(97.56 \%)$ and marginal suitable (S3) (2.44\%) from the total area in Gunung Ambat Village (Figure 2). There were no suitable (S1), and not suitable $(\mathrm{N})$ classes were found in this village. Class S2 means that land has a limiting factor, and this limiting factor will affect its productivity and requiring additional input and Class S3 means that lands having limitations, which are severe for sustained application of a given use and will so reduce productivity or benefits or 
Table 6. Actual land suitability classification for Rambutan (N. lappaceum) in Land Unit V based on the matching method.

\begin{tabular}{llc}
\hline Land characteristics & Field/laboratory data & Actual land suitability \\
\hline $\begin{array}{l}\text { Temperature (tc) } \\
\left({ }^{\circ} \mathrm{C}\right)\end{array}$ & $23{ }^{\circ} \mathrm{C}-24^{\circ} \mathrm{C}$ & $\mathrm{S} 1$ \\
$\begin{array}{l}\text { Water availability (wa) } \\
\left.\text { Rainfall (mm year }{ }^{-1}\right)\end{array}$ & 2010 & $\mathrm{~S} 2$ \\
$\begin{array}{l}\text { Oxygen availability (oa) } \\
\text { Drainage }\end{array}$ & Well drained & $\mathrm{S} 1$ \\
$\begin{array}{l}\text { Root zone medium (rc) } \\
\text { Texture }\end{array}$ & Moderately coarse & $\mathrm{S} 3$ \\
Soil depth (cm) & 77.5 & $\mathrm{~S} 2$ \\
Nutrient retention (nr) & & \\
CEC (me 100g $\left.{ }^{-1}\right)$ & 19.49 & $\mathrm{~S} 1$ \\
pH $\mathrm{H}_{2} \mathrm{O}$ & 6.58 & $\mathrm{~S} 2$ \\
Organic-C (\%) & 1.82 & $\mathrm{~S} 1$ \\
Erosion hazard (eh) & & $\mathrm{S} 3$ \\
Slope (\%) & 30 & $\mathrm{~S} 2$ \\
Erosion hazard & medium & $\mathrm{S} 1$ \\
Flood hazard (fh) & & $\mathrm{S} 3$ rc,eh \\
Inundation & $\mathrm{F} 0$ & \\
Actual land suitability evaluation & & \\
\hline
\end{tabular}

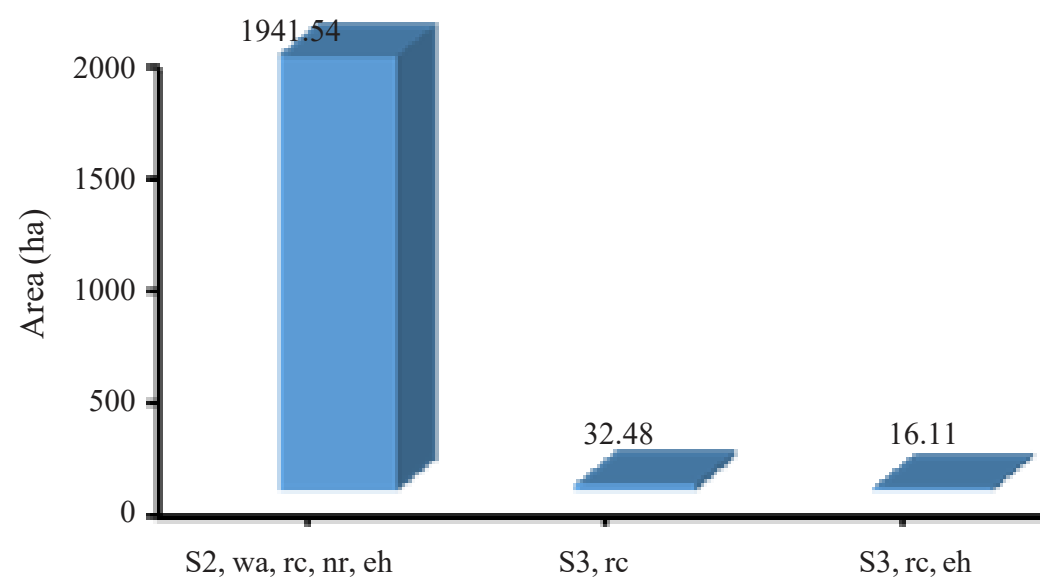

Actual Land Suitability

Figure 2. The area of actual land suitability classes for $N$. lappaceum in Gunung Ambat Village.

increase required inputs that this expenditure will be only marginally justified (FAO 1976).

The actual land suitability classes area of $N$. lappaceum in Simpang Kuta Buluh Village is presented in Figure 3. The actual land suitability classes for $N$. lappaceum were moderately suitable (S2) (52.92\%) and marginal suitable (S3) (47.08\%) from the total area in Simpang Kuta Buluh Village. The same result with actual land suitability classes for $N$. lappaceum in Gunung Ambat Village (availability of water (wa), erosion hazard (eh), root zone medium (rc), and nutrient retention (nr) were the dominant of limiting factor in this area). There were no suitable (S1), and not suitable $(\mathrm{N})$ classes were found in both Gunung Ambat Village and Simpang Kuta Buluh Village.

The actual land suitability map for $N$. lappaceum in Gunung Ambat Village is presented 
Table 7. Actual land suitability classification for Rambutan (N. lappaceum) in Land Unit VI based on the matching method.

\begin{tabular}{|c|c|c|}
\hline Land characteristics & Field/laboratory data & Actual land suitability \\
\hline \multicolumn{3}{|l|}{ Temperature (tc) } \\
\hline$\left({ }^{\circ} \mathrm{C}\right)$ & $23{ }^{\circ} \mathrm{C}-24^{\circ} \mathrm{C}$ & S1 \\
\hline \multicolumn{3}{|l|}{ Water availability (wa) } \\
\hline Rainfall $\left(\mathrm{mm}\right.$ year $\left.{ }^{-1}\right)$ & 2010 & S2 \\
\hline \multicolumn{3}{|l|}{ Oxygen availability (oa) } \\
\hline Drainage & Well drained, medium & S1 \\
\hline \multicolumn{3}{|l|}{ Root zone medium (rc) } \\
\hline Texture & Moderately fine & S1 \\
\hline Soil depth $(\mathrm{cm})$ & 95.33 & S2 \\
\hline \multicolumn{3}{|l|}{ Nutrient retention (nr) } \\
\hline $\mathrm{CEC}\left(\mathrm{me} 100 \mathrm{~g}^{-1}\right)$ & 17.89 & S1 \\
\hline $\mathrm{pH} \mathrm{H} \mathrm{H}_{2} \mathrm{O}$ & 6.62 & S2 \\
\hline Organic-C (\%) & 1.66 & S1 \\
\hline \multicolumn{3}{|l|}{ Erosion hazard (eh) } \\
\hline Slope (\%) & $15 \%$ & $\mathrm{~S} 2$ \\
\hline Erosion hazard & Very low & S1 \\
\hline \multicolumn{3}{|l|}{ Flood hazard (fh) } \\
\hline Inundation & F0 & $\mathrm{S} 1$ \\
\hline Actual land suitability evaluation & & S2 wa,rc,nr,eh \\
\hline
\end{tabular}

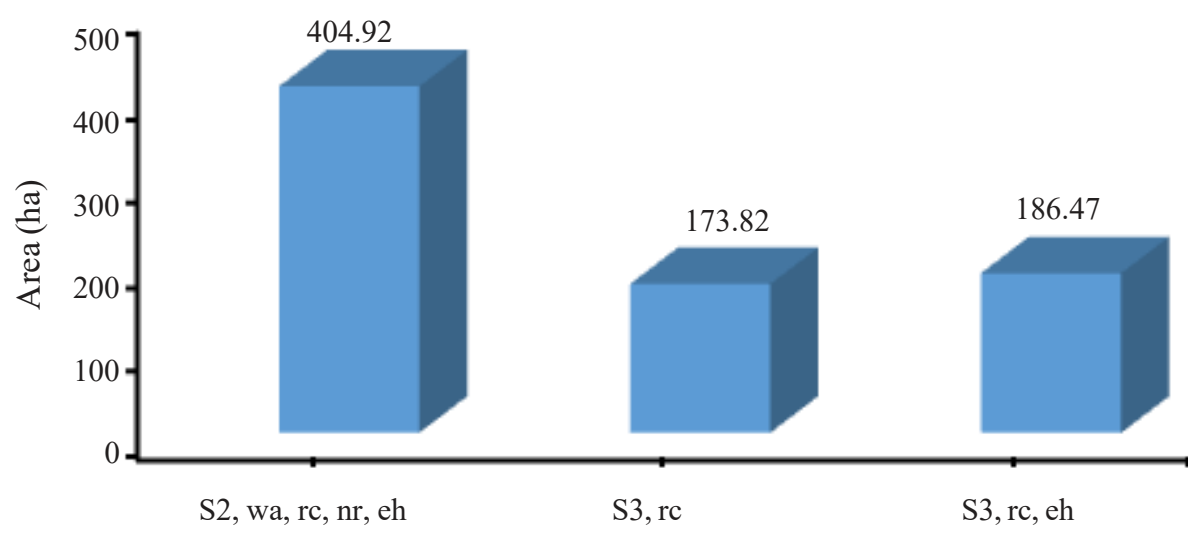

Actual Land Suitability

Figure 3. The area of actual land suitability classes for N. lappaceum in Simpang Kuta Buluh Village.

in Figure 4. and the actual land suitability map for N. lappaceum in Simpang Kuta Buluh Village is presented in Figure 5.

Based on Figure 4 and Figure 5, the development of $N$. lappaceum in both Simpang Kuta Buluh Village and Gunung Ambat still available based on the area of land suitability that dominated by moderately suitable (S2) especially in Land Unit 3,4 , and 6 . There were several limiting factors in land suitability evaluation both in Simpang Kuta Buluh Village and Gunung Ambat, namely: availability of water (wa), erosion hazard (eh), root zone medium (rc), and nutrient retention (nr). Because of natural limitations, root zone medium (rc) and water availability (wa) were the most difficult constrain to counter in this area. Nevertheless, nutrient retention can be improved by fertilization (organic and inorganic) such as by urea and superphosphate fertilizers and the erosion hazard (slope) can be improved by terracing steep areas. For Land Unit 1, 2, 5, and 7, the actual land suitability evaluation was marginally suitable (S3). The root zone medium (rc), were the most difficult constrain to counter in this area. 
Table 8. Actual land suitability classification for Rambutan (N. lappaceum) in Land Unit VII based on the matching method

\begin{tabular}{lll}
\hline Land characteristics & Field/laboratory data & Actual land suitability \\
\hline $\begin{array}{l}\text { Temperature (tc) } \\
\left({ }^{\circ} \mathrm{C}\right)\end{array}$ & $23^{\circ} \mathrm{C}-24^{\circ} \mathrm{C}$ & $\mathrm{S} 1$ \\
$\begin{array}{l}\text { Water availability (wa) } \\
\left.\text { Rainfall (mm year }{ }^{-1}\right)\end{array}$ & & $\mathrm{S} 2$ \\
$\begin{array}{l}\text { Oxygen availability (oa) } \\
\text { Drainage }\end{array}$ & 2010 & $\mathrm{~S} 1$ \\
Root zone medium (rc) & Well drained & \\
Texture & Moderately coarse & $\mathrm{S} 3$ \\
Soil depth (cm) & 58.33 & $\mathrm{~S} 3$ \\
Nutrient retention (nr) & & \\
CEC (me $\left.100 \mathrm{~g}^{-1}\right)$ & 16.90 & $\mathrm{~S} 1$ \\
pH $\mathrm{H}_{2} \mathrm{O}$ & 6.68 & $\mathrm{~S} 2$ \\
Organic-C (\%) & 1.43 & $\mathrm{~S} 1$ \\
Erosion hazard (eh) & & \\
Slope (\%) & $15 \%$ & $\mathrm{~S} 2$ \\
Erosion hazard & Very low & $\mathrm{S} 1$ \\
Flood hazard (fh) & & $\mathrm{S} 1$ \\
Inundation & F0 & $\mathrm{S} 3, \mathrm{rc}$ \\
\hline Actual land suitability evaluation & & \\
\hline
\end{tabular}
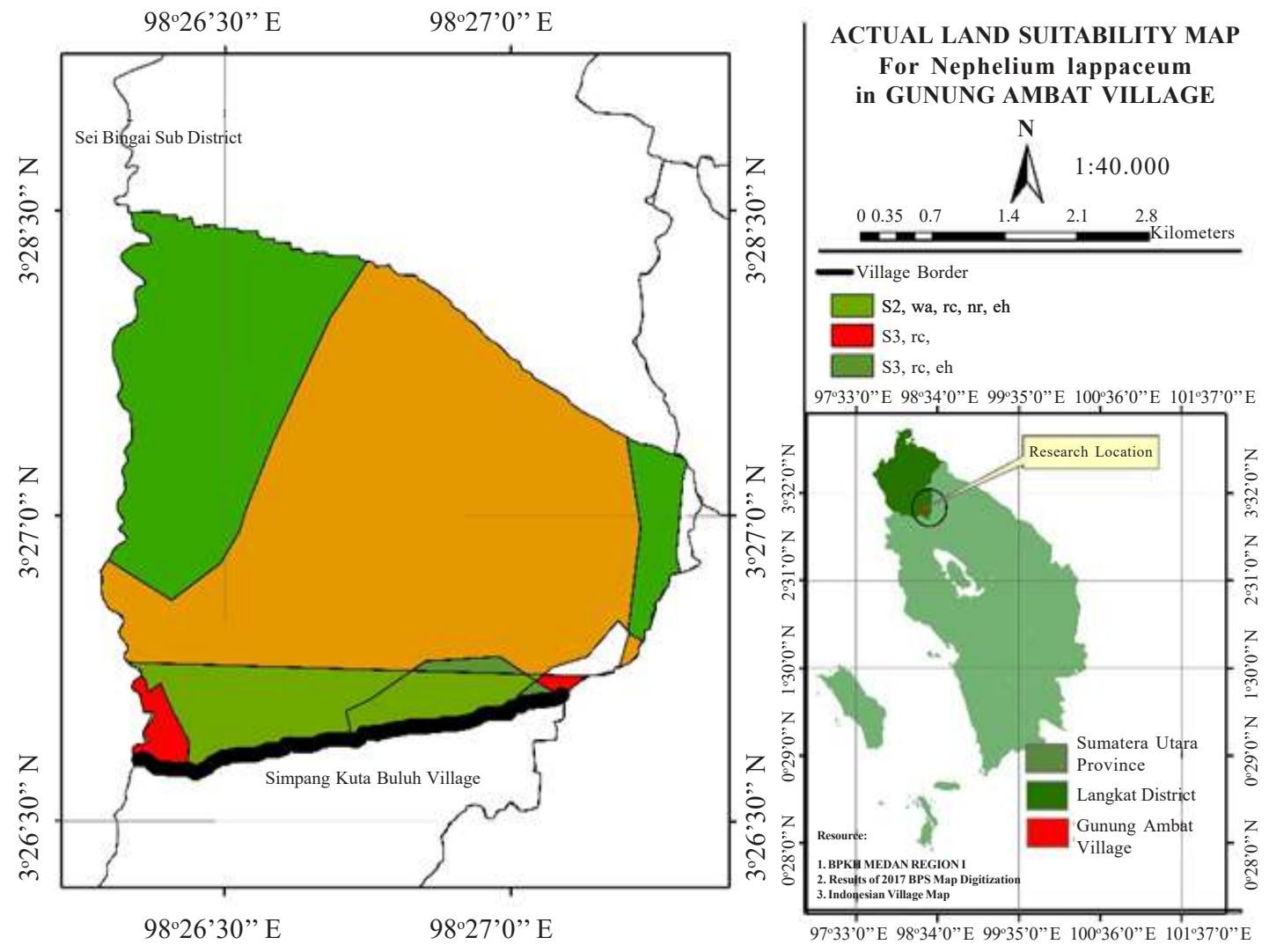

Figure 4. Distribution map of actual land suitability for N. lappaceum in Gunung Ambat Village. 

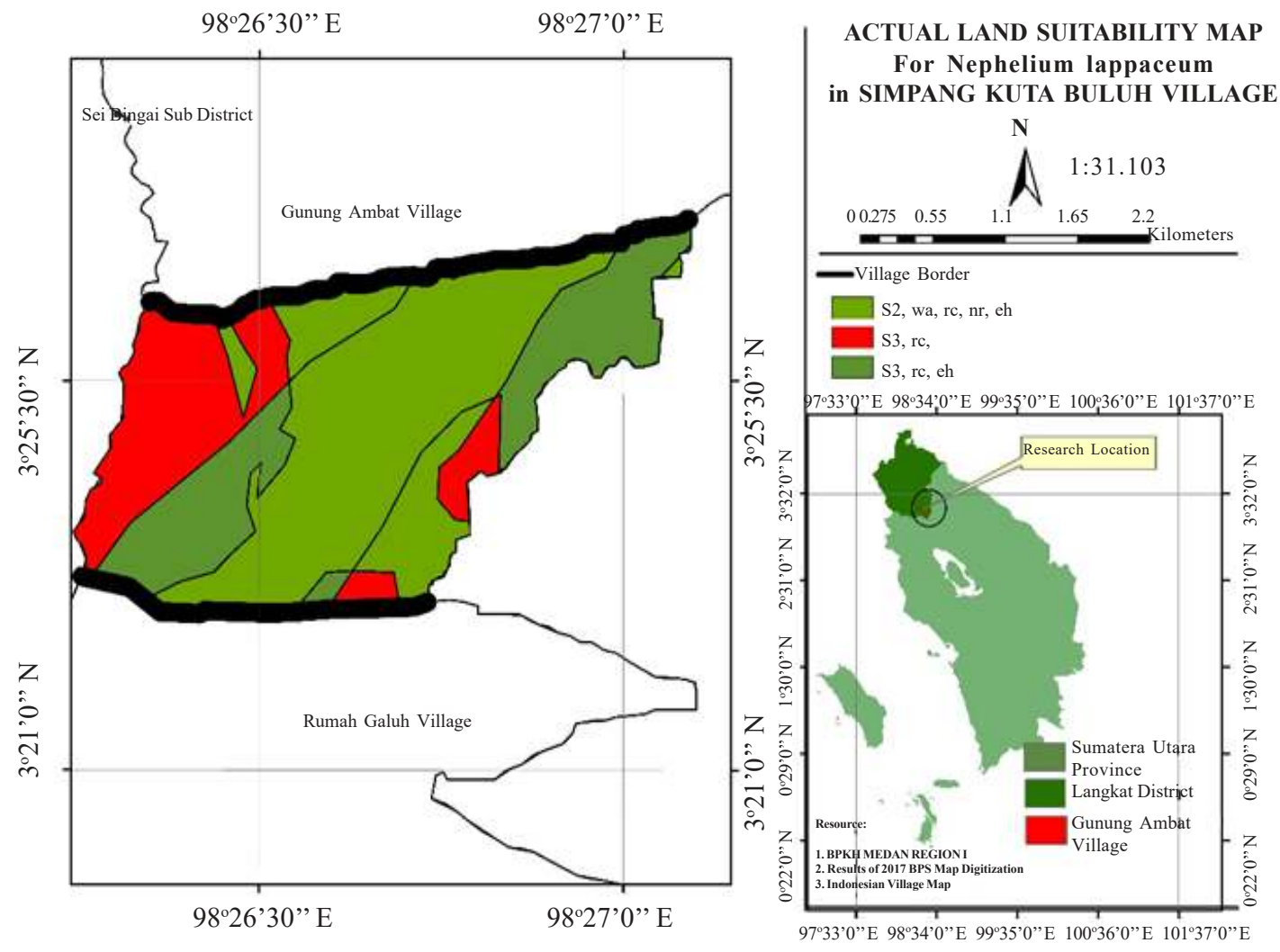

Figure 5. Distribution map of actual land suitability for N. lappaceum in Simpang Kuta Buluh Village.

\section{CONCLUSIONS}

Rambutan (N. lappaceum) is moderately suitable to be developed in Gunung Ambat Village and Simpang Kuta Buluh Village. There were dominant of limiting factor in this area which is difficult to overcome, namely: water availability (wa) inland unit 3, 4, and 6 and root zone medium (rc) in all land units.

\section{ACKNOWLEDGMENTS}

This work was part of a research project about mapping of multipurpose tree species (MPTS) land suitability on three types of land cover in North Sumatera. The research was funded by Universitas Sumatera Utara (USU) based on TALENTA USU Research contract Number: 4167/UN5.1.R/PPM/ 2019 on April 1st 2019. We are grateful to the USU, Organizing Committee of International Seminar and Congress of Indonesian Soil Science Society (ISCOISS 2019) for giving us an opportunity to present this work on August 5-6th 2019, at The Trans Luxury Hotel Bandung, West Java Indonesia. as well as, the students of Department of Forest Management, Faculty of Forestry, USU.

\section{REFERENCES}

Ahmad SAA, UD Palanisamy, BA Tejo, MF Chew, HW Tham and SS Hassan. 2017. Geraniin extracted from the rind of $N$. lappaceum binds to dengue virus type- 2 envelope protein and inhibits the early stage of virus replication. Virol J 14: 229. doi: 10.1186/ s12985-017-0895-1.

Arsyad S. 2010. Soil and Water Conservation $2^{\text {nd }}$ Edition. IPB Press. Bogor. 472p.

Chandio IA and ANB Matori. 2011. Land suitability analysis using Geographic Information System (GIS) for hillside development: A case study of Penang Island. International Conference on Environmental and Computer Science IPCBEE Vol.19, IACSIT Press, Singapore.

Chiaw MWS, A Ismail, NM Esa, GA Akowuah, HC Wai and YH Seng. 2014. The effectiveness of rambutan (Nephelium lappaceum L.) extracts in the stabilization of sunflower oil under accelerated conditions. Antioxidants 3: 371-386.

Chuong HV. 2007. Multi-criteria land suitability evaluation for selected fruit crops in the Hilly region of central Vietnam. Humboldt University, Berlin, Germany.

Djaenudin D, M Hendrisman, H Subagjo and A Hidayat. 2003. Technical guidelines for evaluating land for agricultural commodities. Center for Land and Agro-Climate Research and Development. Bogor. 
El Baroudy AA. 2016. Mapping and evaluating land suitability using a GIS-based model. Catena 140 : 96-104. doi: https://doi.org/10.1016/j.catena. 2015.12.010

Elsheikh R, ARBM Shariff, F Amiri, NB Ahmad, SK Balasundram and MAM Soom. 2013. Agriculture land suitability evaluator (ALSE): A decision and planning support tool for tropical and subtropical crops. Comput Electron Agric 93: 98-110.

FAO [Food and Agriculture Organization]. 1976. A Framework for land evaluation. FAO Soil Bulletin $32.72 p$.

FAO [Food and Agriculture Organization]. 1983. Guidelines: land evaluation for rainfed agriculture. Food and Agriculture Organization of the United Nations, Soils Bulletin 52. Rome, Italy. 79p.

Harahap FS, R Sitompul, A Rauf, Rahmawaty, DE Harahap and $H$ Walida. 2019. Land suitability evaluation for oil palm plantations (Elaeis guenensis jacq.) on Sitellu Tali Urang Julu, Pakpak Bharat District. IOP Conf Ser Earth Environ Sci 260: 012116. doi:10.1088/ 1755-1315/260/1/012116.

Hardjowigeno S and Widiatmaka. 2007. Land Suitability Evaluation and Land Use Planning. Gajah Mada University Press. Yogyakarta.

He Y, Y Yao, Y Chen and L Ongaro. 2011. Regional land suitability assessment for tree crops using remote sensing and GIS. Computer Distributed Control and Intelligent Environmental Monitoring (CDCIEM) IEEE, Changsha, pp. 354-363.

Mahmood K, H Kamilah and AKAF Ariffin. 2018. Nutritional and therapeutic potentials of rambutan fruit (Nephelium lappaceum L.) and the by-products: a review. J Food Meas Charact 12: 1556-1571.

Malczewski J. 2004. GIS-based land-use suitability analysis: a critical overview. Prog Plann 62: 3-65.

Mazahreh S, M Bsoul and DA Hamoor. 2019. GIS approach for assessment of land suitability for different land-use alternatives in a semi-arid environment in Jordan: A case study (Al Gadeer Alabyad-Mafraq). Inf Process Agric 6: 91-108. doi: https://doi.org/10.1016/j.inpa.2018.08.004.

Mirghani MES. 2019. Rambutan (Nephelium lappaceum) Fats in Fruit Oils: Chemistry and Functionality Book 2019, pp.273-280.

Muhamed S, S Kurien, KS Iyer, A Remzeena and S Thomas. 2019. Natural diversity of rambutan (Nephelium lappaceum L.) in Kerala, India. Genet Resour Crop Ev 66: 1073-1090.

Muhtadi, AU Primarianti and TA Sujono. 2015. Antidiabetic activity of durian (Durio zibethinus Murr.) and rambutan (Nephelium lappaceum L.) fruit peels in alloxan diabetic rats. Procedia Food Sci 3: 255-261.

Pan G and J Pan. 2012. Research in cropland suitability analysis based on GIS. In: D Li and Y Chen (eds). Computer and Computing Technologies in Agriculture. International Conference on Computer and Computing Technologies in Agriculture, Beijing, China, Springers, pp. 314-325.
Parry JA, SA Ganaie and MS Bhat. 2018. GIS-based land suitability analysis using AHP model for urban services planning in Srinagar and Jammu urban centers of J\&K, India. J Urban Manag 7: 46-56. doi: https://doi.org/10.1016/j.jum.2018.05.002.

Rahayu L, L Zakir and SA Keban. 2013. The effect of rambutan seed (Nephelium lappaceum L.) infusion on blood glucose and pancreas histology of mice induced with alloxan. J Ilmu Kefarmasian Indonesia 11: 28-35.

Rahmawaty, A Rauf and S Frastika. 2019a. Mapping of actual and potential land suitability for oil palm in several land unit using geographic information system. IOP Conf Ser Earth Environ Sci 260: 012073. doi: 10.1088/1755-1315/260/1/012073.

Rahmawaty, JB Samosir, R Batubara and A Rauf. 2019b. Diversity and distribution of medicinal plants in the Universitas Sumatera Utara Arboretum of Deli Serdang, North Sumatra, Indonesia. Biodiversitas 20: 1457-1465. doi: 10.13057/biodiv/d200539.

Rahmawaty, A Rauf and S Frastika. 2019c. Spatial analysis for Pinus merkusii land suitability at agroforestry land in Telagah Village Sumatera Utara Indonesia. IOP Conf Ser Mater Sci Eng 593: 012017. doi:10.1088/1757-899X/593/1/012017

Rahmawaty, S Frastika, RME Marpaung, R Batubara and A Rauf. 2019d. Short Communication: Use of Geographic Information System for mapping of Aquilaria malaccensis land suitability in North Sumatra, Indonesia. Biodiversitas 20: 2561-2568. doi: https://doi.org/10.13057/biodiv/d200918

Rahmawaty, IEP Sembiring, R Batubara and P Patana. 2018. Mapping of tree damage classification in the western part of Medan City green belts using geographic information system. IOP Conf Ser Earth Environ Sci. 166: 012020. doi: 10.1088/1755-1315/ 166/1/012020.

Rahmawaty, NA Sitorus and A Rauf. 2017a. Distribution, above-ground biomass and carbon stock of the vegetation in Taman Beringin Urban Forest, Medan City, North Sumatra, Indonesia. Malaysian For 80: 73-84.

Rahmawaty, P Patana and S Latifah S. 2017b. Spatial analysis on the distribution of green belt to reduce impacts of climate change in Medan City, North Sumatra Malays. Appl Biol 46: 67-76.

Rahmawaty, NC Siregar and A Rauf. 2016. Land suitability for Tectona grandis: case study in Arboretum Kwala Bekala, Sumatera Utara University. J Penelitian Ekosistem Dipterocarpa 2: 73-82.

Rahmawaty, EK Sari, A Syofyan and A Rauf. 2015. Integrated geographic information system and global positioning system for mapping of forest plants in supporting natural resources protection. Procedia Chem 14: 334-342.

Rahmawaty, A Rauf and HR Sitepu. 2013. Geographic information system application for mapping the suitability of eucalyptus and durian land as agroforestry plants. Proceedings of the National Seminar on Agroforestry IV. Fahutan Unlam Press, pp. 660-669. 
Rahmawaty, TR Villanueva, MG Carandang, RL Lapitan, NC Bantayan and AJ Alcantara. 2012. Land suitability for oil palm in Besitang Watershed, North Sumatra, Indonesia. Sci J Agric Res Manage, 6p. doi: $10.7237 /$ sjarm/124.

Rahmawaty, TR Villanueva and MG Carandang. 2011. Participatory land-use allocation, a case study in Besitang Watershed, Langkat, North Sumatera, Indonesia. Lambert Academic Publishing. German. 200p.

Ritung S, K Nugroho, A Mulyani and E Suryani. 2011. Technical Guidelines for Evaluating Land for Agricultural Commodities (Revised edition). Agricultural Research and Development Agency. Bogor. 168p.

Ritung S, Wahyunto, F Agus and H Hidayat. 2007. Land Suitability Evaluation Guidance. Land Research Center and the World Agroforestry Center. Bogor.

Satriawan H, EM Harahap, Rahmawaty and A Karim A. 2015. Effectiveness of soil conservation to erosion control on several land-use types. Agriculture (Pol'nohospodárstvo) 61: 61-68. doi: https:// doi.org/10.1515/agri-2015-0011.
Satriawan H, EM Harahap, Rahmawaty and A Karim. 2014. Land capability evaluation for agriculture in Krueng Sieumpo Watershed, Aceh. Acad Res Int 5: 55-63.

Soil Research Center. 2003. Technical Guidelines for Evaluating Land for Agricultural Commodities. Center for Land Research and Development and Agro-climatology Agricultural Research and Development Agency Agriculture Department. Bogor.

Sukmandari NS, Dash G, Jusof WHW and Hanafi M. 2017. A review on Nephelium lappaceum L. Res J Pharm Technol 10: 2819-2827. doi: 10.5958/0974360X.2017.00498.X .

Syarifuddin, E Hafnisiregar, J Jambak and C Suryani. 2018. The impact of oil palm plantation on the ecology of rambutan (Nephelium lappaceum) insect pollinators. Biodiversitas 19: 1347-1351. doi: https:/ /doi.org/10.13057/biodiv/d190422.

Tarigan A, A Rauf and Rahmawaty. 2016. Land suitability evaluation for potato in the Karo District Siosar Relocation Area. J Pertanian Tropik 3: 124-131.

Zonneveld IS. 1989. The land unit - a fundamental concept in landscape ecology, and its applications. Landsc Ecol 3: 67-86. 